\title{
Evaluation of minimally invasive plate osteosynthesis of distal femoral fracture by mini-open technique with femoral distractor and traction table: a prospective review of 26 cases
}

\author{
Tapas Kumar Ghosh, Rajeeb Banik*, Bijoy Bhattacharjya
}

Department of Orthopaedics, North Bengal Medical College, Sushrutanagar, Siliguri, Darjeeling, West Bengal, India

Received: 05 July 2020

Revised: 04 August 2020

Accepted: 05 August 2020

\author{
*Correspondence: \\ Dr. Rajeeb Banik, \\ E-mail: rbrgkmso@gmail.com
}

Copyright: (c) the author(s), publisher and licensee Medip Academy. This is an open-access article distributed under the terms of the Creative Commons Attribution Non-Commercial License, which permits unrestricted non-commercial use, distribution, and reproduction in any medium, provided the original work is properly cited.

\begin{abstract}
Background: Different methods exist for fracture reduction and submuscular plating in distal femur intra-articular and metaphyseal extra-articular fractures. Apart from knee flexion, femoral distractor and traction table are commonly used for alignment of fractures in minimally invasive techniques.

Methods: 26 distal femoral fractures (all closed fractures) were operated (14 cases in traction table, 12 cases in femoral distractor). Partial articular/unicondylar fractures were excluded from our study. Mean patient age was 42 years (range 18 to 60 years). Evaluation was done by knee society score (KSS).

Results: Mean time of radiological union was 23.2 weeks (range 20-28 weeks). 23 fractures united uneventfully, one patient had wound infection, and 2 cases had non-union with implant failure. Debridement in infected implant and refixation with long plate and bone grafting were done for fracture union in these two cases. According to KSS, excellent outcome were seen in 6 patients, 10 had good, 8 had fair and 2 had poor outcome.

Conclusions: Distraction by traction table or femoral distractor helps us to reduce the fracture by overcoming the pull of gastrocnemius in 2 week old fracture correcting hyperextension/recurvatum deformity. This method can be used as viable alternative in minimally invasive plating causing less chance of infection preserving maximal joint movement.
\end{abstract}

Keywords: Submuscular plating, Femoral distractor, Traction table, Knee society score

\section{INTRODUCTION}

Distal femur fractures (intra-articular and extra-articular both) account for approximately $6 \%$ of all fractures of the femur. The fractures follow a bimodal age pattern. These fractures typically occur after high-energy trauma such as road traffic accidents or fall from heights in younger patients or after trivial trauma in the elderly (mostly females) with osteoporotic bone. ${ }^{1}$

From the era of cast bracing and traction in 1960; spanning external fixator in open distal femur fractures to the development of internal fixation devices like distal femoral nail, plate fixation is recognized as the treatment of choice for most distal femoral fractures. $95^{\circ}$ blade plate, dynamic condylar screw, condylar buttress plate have paved the way for pre-contoured distal femoral locking plate with fixed angle locking screw construct and less invasive surgical stabilization (LISS). The conventional open reduction and internal fixation is changing towards a more biological and minimally invasive approach, with preservation of subperiosteal blood supply, fracture haematoma and careful handling of the soft-tissue envelope. $^{2}$

Newer pre-contoured implants with fixed angle locking screw system have the advantage to protect the subperiosteal blood supply and soft tissues attachment of bony fragments by indirect reduction techniques. ${ }^{3}$ In minimally invasive plate osteosynthesis (MIPO), 
precontoured plate is slid through submuscular tunnel after aligning the fracture. Ultimately the locking plate is fixed by percuteneous screws placed through multiple stab incisions through skin. ${ }^{4,5}$

The gastrocnemius typically causes a hyperextension deformity of the distal femoral articular block. Hyperextension deformity must be corrected before fracture fixation. Aids to correcting this hyperextension deformity include: a bolster in the supracondylar region and knee flexion upto $30^{\circ}$, traction (manual/traction table), insertion of a schanz pin from anterior to posterior in the distal femoral articular block which can be used to correct hyperextension and femoral distractor/spanning exfix. ${ }^{6}$

Although placement of a bump/bolster and flexing knee upto $30^{\circ}$ is used most commonly for reduction of metaphyseal region of distal femur fracture in MIPO, we preferred traction table and femoral distractor for submuscular plating in 26 patients presenting with distal femur fracture.

\section{METHODS}

The study was performed in the Department of Orthopaedics, North Bengal Medical College from August 2016 to July 2018. 26 distal femur fracture (both extraarticular and intra-articular) were operated.

\section{Inclusion criteria}

Distal femoral extra-articular fractures (AO 33A1, 33A2, 33A3 type of fractures), distal femoral fractures with simple intra-articular fracture (AO 33C1, 33C2 type of fractures) were included.

\section{Exclusion criteria}

Partial articular fractures (unicondylar): AO 33B1, 33B2, 33B3 type of fractures, distal femur fracture with multifragmentary articular communition: 33C3 type of fractures, intra-articular distal femur fractures that were presented late $>3$ weeks since injury, distal femur fracture with proximal femur/tibia fracture in ipsilateral limb, open fractures and pathological fracture were excluded.

The average days we waited for operation is between 7-14 days. We used fracture table with traction apparatus or distractor to overcome the muscle pull by gastrocnemius muscle. Most of the fractures were reduced by indirect methods. $^{7}$

Traction table with posterior femoral clamp prevents hyperextension of fracture and distractor maintains length, alignment, corrects varus/valgus angulation. In distal femur fractures that were presented late, we used femoral distractor for obtaining alignment and reduction. In femoral distractor application, one steinman pin placed in the femur and one at the tibia anterior to posteriorly/lateral to medially to correct recurvatum/procurvatum deformity and medio-lateral angulation. ${ }^{6}$

Intra operative fluoroscopy was done for axial alignment, rotation, varus-valgus angulation, intra-articular congruity and screw placement. Steinman`s pin/schanz screws were used for fracture reduction as a joystick.

Under fluoroscopic guidance, an oblique incision was made over the lateral aspect of the distal femur at the level of the intercondylar notch. The breadth of the incision was 0.5 to $1 \mathrm{~cm}$ more than the maximum width of the metaphyseal flare of the plate. The tensor fascia lata was split along the direction of its fibres. A submuscular tunnel was created using an osteotome. Following reduction, appropriate-sized plates (with 6 to 12 holes) were slid in a distal-to-proximal direction over the lateral aspect of the distal femur. The length of the plate was determined intraoperatively after reduction. Plate was provisionally fixed with $\mathrm{K}$-wire and plate position was checked with carm image intensifier.

Intra-articular congruity was maintained by traction and checked by intra-operative fluoroscopy. In intra-articular fractures which needed open reduction, lateral/medial parapatellar arthrotomy was done, fragments manipulated with $2.5 \mathrm{~K}$-wire as joystick, provisionally fixed with 6.5 cannulated cancellous screw from medial to lateral side or lateral to medially without occupying the space for locking plate placement. Proximal screws were bicortical mostly. For distal fixation, 3/4 metaphyseal locking screws were used; their sizes did not violate the intercondylar notch space. A small incision over the proximal portion of the plate enabled reduction of the fracture and placement of compression screws/locking screws as necessary. ${ }^{8}$

We used corticocancellous bone grafting from ipsilateral iliac crest in case of bone loss and in re-fixation cases.

In distal femoral fractures active knee mobilization and static quadriceps exercises were allowed at postoperative day 1 . Weight bearing was initiated depending on the radiological evidence of bone union. Full weight bearing was not permitted until consolidation of the fracture site. The progress of healing was assessed with routine anteroposterior and lateral radiographs at 4 weekly intervals up to 24 weeks, then every 3 months up to one year, and 6 monthly thereafter. Bone union was defined as bridging callus across the fracture site on both anteroposterior and lateral radiographs. Partial weight bearing allowed when bridging callus seen in minimal two cortices, full weight bearing given when the fracture union seen in minimal three cortices.

Evaluation was done by knee society score and functional score. ${ }^{9}$

Components of knee society score are pain, flexion contracture, extensor lag, total range of motion (ROM) of flexion, varus-valgus alignment, stability in antero- 
posterior and medio-lateral plane. Functional score is based on walking, stairs and walking aids used.

Grading of knee society score: score $>80$ graded as excellent, score between 70-79 graded as good, score between 60-69 regarded as fair and score less than 60 considered as poor.

Statistical analysis was done with the help of computer using statistical package for social sciences (SPSS software, version 22.0 for Windows).

\section{RESULTS}

The patients included in the study had an average age of 42 years (range 18-60 years).

Out of the 26 patients 15 were male and 11 were female. All fractures were closed fracture. Road traffic accidents were the commonest mode of trauma.

According to extra-articular fracture 33A2 fracture was highest (7) followed by 33A1 (6) and 33A3 (4). In articular fracture $33 \mathrm{C} 1$ sample size was $6,33 \mathrm{C} 2$ was 3 (Table 1). 33B1, 33B2, 33B 3 and 33C 3 fractures were excluded from the study.
Table 1: Number of cases operated by different modalities $(n=26)$.

\begin{tabular}{|llll|}
\hline $\begin{array}{l}\text { Type of } \\
\text { fractures }\end{array}$ & $\begin{array}{l}\text { Operated in } \\
\text { fracture } \\
\text { table }\end{array}$ & $\begin{array}{l}\text { Operated } \\
\text { by femoral } \\
\text { distractor }\end{array}$ & $\begin{array}{l}\text { Total no. } \\
\text { of patients }\end{array}$ \\
\hline 33A1 & $3(11.5)$ & $\mathbf{N}(\%)$ & $\mathbf{N}(\%)$ \\
\hline 33A2 & $4(15.4)$ & $3(11.54)$ & $6(23.1)$ \\
\hline 33A3 & $2(7.7)$ & $2(7.7)$ & $4(15.4)$ \\
\hline 33C1 & $3(11.5)$ & $3(11.54)$ & $6(23.4)$ \\
\hline 33C2 & $2(7.7)$ & $1(3.8)$ & $3(11.5)$ \\
\hline Total & $14(53.84)$ & $12(46.16)$ & $26(100)$ \\
\hline
\end{tabular}

18 fractures were presented within 1 week and 8 fractures were presented after 2 weeks. These 8 fractures that were included in the study were extra-articular fractures. 14 fractures were aligned by traction table, joystick by schanz screw application, use of reduction clamp and submuscular locking plate placement by MIPO technique (Figure 1). 12 fractures needed femoral distractor for articular congruity and length, angulation and rotational alignment (Figure 2). They were reduced by limited miniopen approach and locking plate placement. Bone grafting done in case of bone loss in distal femur fracture and in refixation cases.

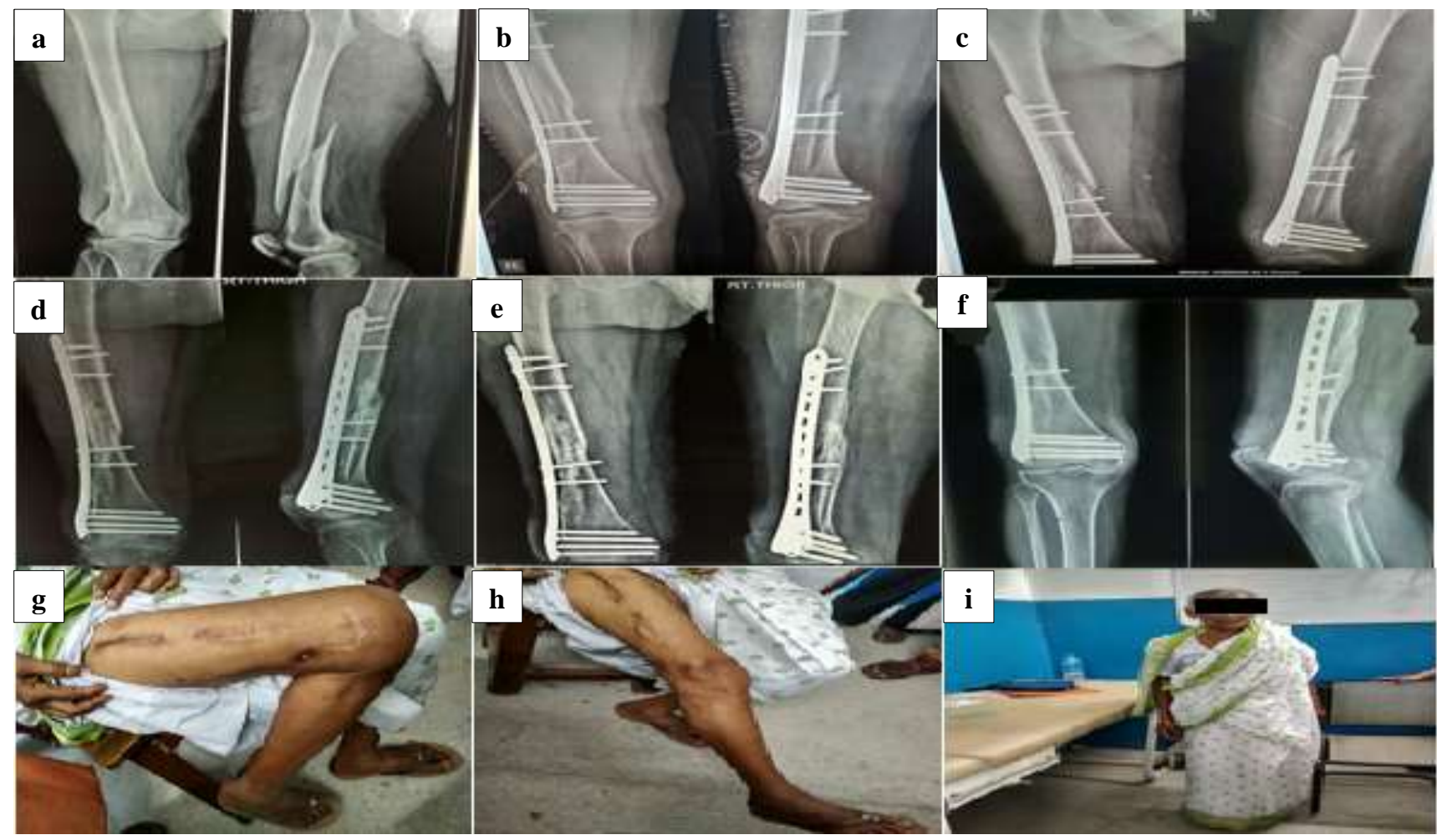

Figure 1: (a) 33A1 fracture right femur treated with MIPO (traction table), (b) immediate post-op x-ray, (c)-(f) xray at 4, 8, 12 and 24 week post-op respectively, (g)-(i) at 24 weeks, knee flexion, healed scar mark and standing without support respectively. 


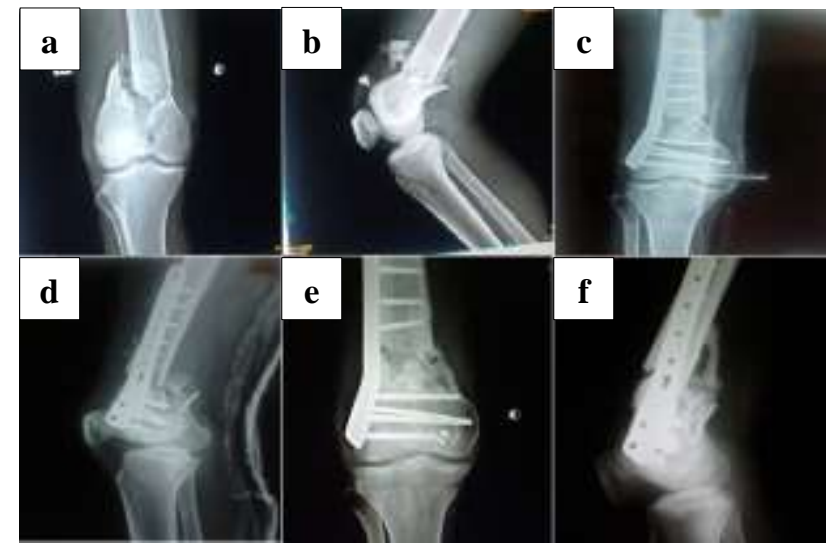

Figure 2: (a and b) 33C2 right distal femoral fracture operated by femoral distractor, (c) and (d) post-op $x$ ray, (e) and (f) follow up x-ray at 12 weeks.

Mean time of radiological union was 23.2 weeks (range 20-28 weeks). 23 fractures united uneventfully, one patient had wound infection which was treated by wound debridement and antibiotic therapy and subsequent implant removal after fracture union, 2 cases had nonunion with implant failure in which one case had infected implant (Figure 3). In these two cases, fracture type was 33A3 group. Implant removal, debridement with refixation of fracture with long plate and bone grafting subsequently done in those 2 cases (Figure 4 ). Those cases united after 24 weeks.

At 12 months follow up, 6 patients had achieved more than $100^{\circ}$ of flexion at the knee, in 9 patients had less than $10^{\circ}$ extension lag and in 4 patients had greater than $10^{\circ}$ extension lag, rest of the patients (13) had no extensor lag. In all patients, varus/valgus alignment were within $10^{\circ}$ (Table 2).

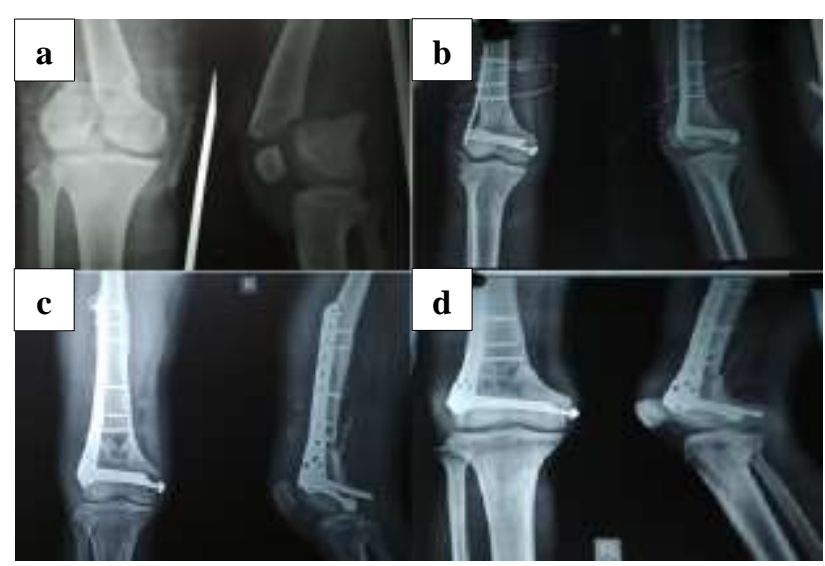

Figure 3: (a and b) 33C1 fracture right femur treated with mini-invasive plating (with femoral distractor),

(c) and (d) follow up x-ray at 8 week and 20 week showing progression of fracture healing despite infection.

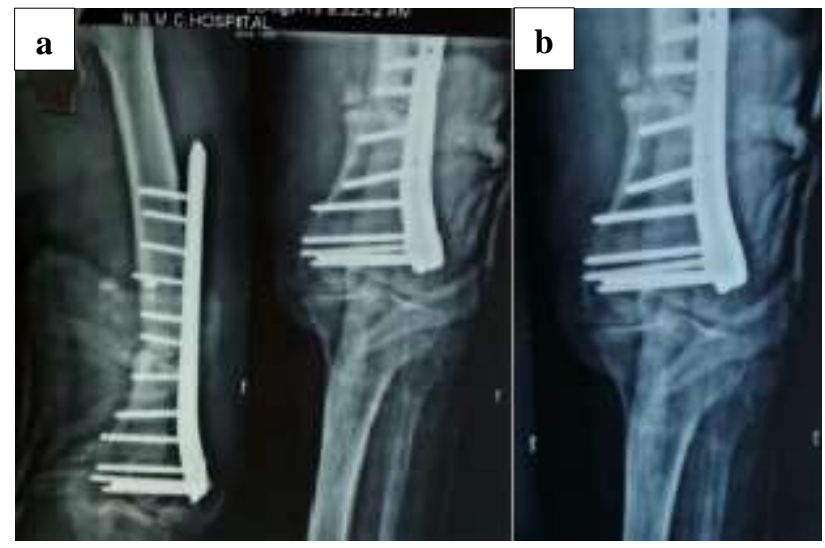

Figure 4 (a and b): Re-fixation in a case of implant failure in left distal femur fracture.

Table 2: Follow up at 12 months.

\begin{tabular}{|c|c|c|c|c|c|c|c|c|}
\hline $\begin{array}{l}\text { Type of } \\
\text { fracture }\end{array}$ & $\begin{array}{l}\text { Mean time } \\
\text { taken for } \\
\text { fracture } \\
\text { union }\end{array}$ & $\begin{array}{l}\text { Full } \\
\text { weight } \\
\text { bearing }\end{array}$ & Pain & $\begin{array}{l}\text { Varus/ } \\
\text { valgus } \\
\text { alignment }\end{array}$ & $\begin{array}{l}\text { Extensor } \\
\text { lag }\end{array}$ & $\begin{array}{l}\text { Range of } \\
\text { terminal } \\
\text { flexion }\end{array}$ & Mean KSS & $\begin{array}{l}\text { Mean } \\
\text { functional } \\
\text { score }\end{array}$ \\
\hline $\begin{array}{l}33 A 1 \\
(n=6)\end{array}$ & 24 week & 20 week & $\begin{array}{l}\text { Mild (2 } \\
\text { patients) }\end{array}$ & $5^{0}-10^{0}$ & $\begin{array}{l}0^{\circ}-10^{\circ}(3 \\
\text { patients })\end{array}$ & $100^{\circ}-110^{\circ}$ & $\begin{array}{l}85 \\
\text { (excellent) }\end{array}$ & 73 (good) \\
\hline $\begin{array}{l}33 \mathrm{~A} 2 \\
(\mathrm{n}=7)\end{array}$ & 22 week & 18 week & $\begin{array}{l}\text { Mild (3 } \\
\text { patients) }\end{array}$ & $0^{\circ}-10^{\circ}$ & $\begin{array}{l}0^{0}-5^{\circ}(4 \\
\text { patients })\end{array}$ & $90^{\circ}-95^{\circ}$ & $77($ good $)$ & 65 (fair) \\
\hline $\begin{array}{l}\text { 33A3 } \\
(n=4)\end{array}$ & 28 week & 24 week & $\begin{array}{l}\text { Mild (stairs } \\
\text { only) } \\
\text { ( } 2 \text { patients) }\end{array}$ & $0^{0}-5^{0}$ & $\begin{array}{l}0^{\circ}-10^{\circ}(2 \\
\text { patients })\end{array}$ & $\begin{array}{l}90^{\circ}-100^{\circ} \\
\left(* 80^{\circ} \text { in } 2\right. \\
\text { patients })\end{array}$ & 71 (good) & 64 (fair) \\
\hline $\begin{array}{l}33 C 1 \\
(n=6)\end{array}$ & 20 week & 16 week & $\begin{array}{l}\text { Mild (stairs } \\
\text { only) } \\
\text { (3 patients) }\end{array}$ & $5^{0}-10^{0}$ & $\begin{array}{l}10^{\circ}-15^{\circ}(2 \\
\text { patients })\end{array}$ & $90^{\circ}-100^{\circ}$ & 69 (fair) & 70 (good) \\
\hline $\begin{array}{l}33 \mathrm{C} 2 \\
(\mathrm{n}=3)\end{array}$ & 22 week & 16 week & $\begin{array}{l}\text { Mild (stairs } \\
\text { and } \\
\text { walking) (2 } \\
\text { patients) }\end{array}$ & $0^{\circ}-10^{\circ}$ & $\begin{array}{l}10^{\circ}-15^{\circ}(2 \\
\text { patients })\end{array}$ & $80^{\circ}-95^{\circ}$ & 61 (fair) & 60 (fair) \\
\hline
\end{tabular}


Table 3: Mean and standard deviation (SD) of various parameters of fractures treated by various methods.

\begin{tabular}{|lllll|}
\hline Variables & \multicolumn{4}{c}{ Tean \pm SD (range) } \\
\hline $\begin{array}{l}\text { Weeks taken for fracture } \\
\text { union }\end{array}$ & $23.2 \pm 2.71(20-28)$ & Traction table $(\mathbf{n}=14)$ & Femoral distractor $(\mathbf{n = 1 2})$ & P value \\
\hline $\begin{array}{l}\text { Partial weight bearing in } \\
\text { weeks }\end{array}$ & $12.8 \pm 1.6(12-16)$ & $13.2 \pm 1.6(12-65(20-28)$ & $22.8 \pm 2.04(20-26)$ & 0.403 \\
\hline Full weight bearing in weeks & $18.8 \pm 2.99(16-24)$ & $19.2 \pm 2.71(16-24)$ & $12.4 \pm 0.8(12-14)$ & 0.13 \\
\hline Knee society score & $72.6 \pm 8.04(81-85)$ & $73 \pm 7.48(63-85)$ & $72 \pm 7.16(61-82)$ & 0.432 \\
\hline Functional score & $66.4 \pm 4.59(60-73)$ & $66.8 \pm 4.07(62-73)$ & $65.8 \pm 3.81(60-70)$ & 0.732 \\
\hline
\end{tabular}

Table 4: Outcome of different fracture according to knee society score and functional score.

\begin{tabular}{|lllllllll|}
\hline \multirow{2}{*}{$\begin{array}{l}\text { Fracture } \\
\text { type }\end{array}$} & Excellent & Good & Fair & Poor & Excellent & Good & Fair & Poor \\
\hline 33A1 & $\mathbf{N}(\%)$ & $\mathbf{N}(\%)$ & $\mathbf{N}(\%)$ & $\mathbf{N}(\%)$ & $\mathbf{N}(\%)$ & $\mathbf{N}(\%)$ & $\mathbf{N}(\%)$ & $\mathbf{N}(\%)$ \\
\hline 33A2 & $2(7.4)$ & $2(7.7)$ & 0 & 0 & 0 & $4(15.4)$ & $2(7.7)$ & 0 \\
\hline 33A3 & 0 & $2(11.5)$ & $2(7.7)$ & 0 & 0 & $3(11.5)$ & $4(15.4)$ & 0 \\
\hline 33C1 & 0 & $2(7.7)$ & 0 & $2(7.7)$ & 0 & 0 & $2(7.7)$ & $2(7.7)$ \\
\hline 33C2 & 0 & $1(3.8)$ & $2(7.7)$ & 0 & 0 & $1(3.8)$ & $2(7.7)$ & 0 \\
\hline Total & $6(23.1)$ & $10(38.4)$ & $8(30.8)$ & $2(7.7)$ & 0 & $12(46.15)$ & $12(46.15)$ & $2(7.7)$ \\
\hline
\end{tabular}

Fracture healed in mean duration of $23.2 \pm 2.71$ weeks (range 20-28 weeks), while full weight bearing resumed on $18.8 \pm 2.99$ weeks (range 16-24 weeks). Mean knee society score and mean functional score were $72.6 \pm 8.04$ (range 81-85) and 66.4 \pm 4.59 (range 60-73) respectively (Table 3). Though fractures treated by femoral distractor had quicker recovery compared to fractures operated by traction table in respect to fracture healing time, time taken for partial and full weight bearing; mean knee society score and mean functional score were better in fractures dealt with traction table. However, the results were not statistically significant ( $p$ value $>0.05$ ). In our study knee society score (KSS) and functional score was used to evaluate the final outcome at 12 months. According to KSS excellent outcome seen in 6 patients, 10 had good, 8 has fair and 2 had poor outcome. According to functional score good and fair results seen in 12 patients each and 2 patients had poor result (Table 4). 2 patients who had 33A3 fracture, resulted poor outcome due to implant failure and undergone subsequent revision surgery with bone grafting and long locking plate fixation.

\section{DISCUSSION}

Various treatment methods have been used for distal femoral fractures. They include direct-indirect reduction, open-minimal invasive approaches and involve condylar plates, dynamic condylar screws, condylar buttress plates, anterograde nails, retrograde nails, internal fixators and external fixators. ${ }^{10}$

The advantages of indirect fracture reduction and submuscular plating in the treatment of fractures of the distal femur lie in the fact that the soft-tissue envelope surrounding the fracture remains largely intact, thus preserving the biology and enhancing the chances of fracture union, reducing the need for bone grafting as well as the incidence of infection. ${ }^{11}$

Also, while relative stability is adequate for the metaphyseal/diaphyseal region, absolute stability using compression with lag screw fixation is required for articular fractures. Minimally invasive plate osteosynthesis is particularly suitable for types 33-A2, 33A3 and 33-C fractures.

Indirect reduction achieved by various means, such as using bump in the posterior aspect of supracondylar region of femur, manual traction, percuteneous instruments, fracture table with clamp placed in posterior aspect of distal femur, femoral distractor, schanz screw inserting anterior to posterior to correct hyperextension deformity of distal fragment. ${ }^{12}$

Locking compression plate (LCP) permits simultaneous application of locking screws as well as cortical screws in the same plate. This "hybrid"-fixation technique enables interfragmentary compression using excentric drilling or lag screw application in simple fracture patterns, as well as the combination with locking screws having the advantage of better fixation that theoretically increases screw pull-out strength in osteoporotic bone.

Distal femur fracture more than 2 weeks old pose a difficult problem in our scenario. The pull of gastrocnemius causes recurvatum deformity, to reduce sagital plane alignment, open reduction of fracture and release of soft tissue from the posterior aspect of distal 
fragment might be necessary but it poses risk of extensive periosteal stripping, more blood loss and more chance of post-op infection and stiffness of knee joint.

Traction table and femoral distractor help to overcome the pull of gastrocnemius in extended position of knee, thus aiding in fracture reduction. Schanz screw and reduction clamp corrects the recurvatum/procurvatum and varus/valgus deformity. ${ }^{6}$

In our study KSS and functional score was used to evaluate the final outcome at 12 months. According to KSS, 6 (23\%) patients had excellent, $10(38 \%)$ had good, $8(31 \%)$ has fair and $2(8 \%)$ had poor outcome. According to functional score good and fair results seen in 12 patients each $(46 \%)$ and 2 patients $(8 \%)$ had poor result. Poor outcome seen in 2 patients who had 33A3 fracture, had implant failure and had subsequent revision surgery with bone grafting and long locking plate fixation. Better mean knee society score and mean functional score seen in 33A1 fractures, followed by $33 \mathrm{~A} 2$ and 33A3. Among intraarticular fracture $\mathrm{C} 1$ type had better result than $\mathrm{C} 2$.

Though fractures treated by femoral distractor healed quickly compared to fractures operated by traction table; mean KSS and mean functional score were better in fractures treated with traction table. However the results were not statistically significant.

There was a paper by Chandrasekharan et al on 2016, where 23 distal femur fracture was treated by locking compression plate by MIPO technique. Result was excellent in $16(69 \%)$ patients followed by good result in $5(21 \%)$ patients. Two patients had fair outcome. No patients had poor outcome. ${ }^{13}$

Another paper by Walia et al on 2014, 50 distal femur fracture were operated by minimally invasive plate osteosynthesis, excellent result seen in 18 patients, good results obtained in 28 patients, where 4 cases had poor results. ${ }^{14}$

\section{CONCLUSION}

MIPO using a LCP achieves favourable biological fixation for distal femoral fractures with few complications. Distraction by traction table or femoral distractor helps us to reduce the fracture by overcoming the pull of gastrocnemius in 2 weeks old fracture correcting hyperextension/recurvatum deformity, with the percuteneous reduction clamp or schanz screw reducing the fracture with proper alignment limiting the length of incision and soft tissue dissection even in intra-articular fractures. ${ }^{15}$ As a result, less chance of infection and less loss of range of motion of knee joint occurs in minimally invasive plate fixation.

Although flexing the knee joint and placing a bump beneath the knee is more commonly used to relax the gastrocnemius and reducing the distal femur fracture by minimally invasive approach in fresh fractures, it requires open reduction in fractures $>2$ weeks old. So this method is a viable alternative approach and specially can be used in both extra-articular and complete intra-articular fracture (with and without metaphyseal communition).

\section{Funding: No funding sources}

Conflict of interest: None declared

Ethical approval: The study was approved by the institutional ethics committee

\section{REFERENCES}

1. Higgins TF. Distal femoral fractures. J Knee Surg. 2007;20:56-66.

2. Weller S. Biological fracture fixation-what is this? Is it another traumatological fashion or an important aspect of operating technique?. IGOF News. 1997;1.

3. Miclau T, Martin RE. Evolution of modern plate osteosynthesis. Injury. 1997;28(1):3-5.

4. Egol KA, Kubiak EN, Fulkerson E, Kummer FJ, Koval KJ. Biomechanics of locked plates and screws. J Orthop Trauma. 2004;18:488-93.

5. Stoffel K, Dieter U, Stachowiak G, Gachter A, Kuster MS. Biomechanical testing of the LCP-how can stability in locked internal fixators be controlled?. Injury. 2003;34(2):11-9.

6. Babst R, Bavonratanavech S, Pesantez R. minimally invasive plate osteosynthesis second expanded edition. AO foundation, Switzerland. Thieme. 2012;421.

7. Leunig M, Hertel R, Siebenrock KA, Ballmer FT, Mast JW, Ganz R. The evolution of indirect reduction techniques for the treatment of fractures. Clin Orthop Relat Res. 2000;375:7-14.

8. Kregor PJ, Stannard JA, Zlowodzki M, Cole PA. Treatment of distal femur fractures using the less invasive stabilization system: surgical experience and early clinical results in 103 fractures. J Orthop Trauma. 2004;18:509-20.

9. Insall JN, Dorr LD, Scott RD, Scott WN. Rationale of the Knee Society clinical rating system. Clin Orthop Relat Res. 1989;248:13-4.

10. Hontzsch D. Distal femoral fracture-technical possibilities. Kongressbd Dtsch Ges Chir Kongr. 2001;118:371-4.

11. Greiwe RM, Archdeacon MT. Locking plate technology: current concepts. J Knee Surg. 2007;20:50-5.

12. Hammer C, Afolayan J, Trompeter A, Elliott D. A novel approach to closed reduction of distal femur fractures. Ann R Coll Surg Engl. 2014;96(8):626-8.

13. Chandrasekaran M, Subbaraj R, Nandakumar R, Reddy KB. Distal femur fractures treated with MIPO locking compression plate technique: a prospective study on the functional outcome. Int $\mathrm{J}$ Orthop Traumatol Surg Sc. 2016;2(2):263-8.

14. Walia JPS, Malu G, Walia SK, Gupta AC, Sethi S, Singh S. Minimally invasive plate osteosynthesis for distal femoral fractures. JIMSA. 2014;27(4). 
15. Kumar GNK, Sharma G, Farooque K, Sharma V, Ratan R, Yadav S, et al. Locking compression plate in distal femoral intra-articular fractures: our experience. Int Scholar Res Notices. 2014;1:1-5.
Cite this article as: Ghosh TK, Banik R, Bhattacharjya B. Evaluation of minimally invasive plate osteosynthesis of distal femoral fracture by mini-open technique with femoral distractor and traction table- a prospective review of 26 cases. Int $\mathbf{J}$ Res Orthop 2020;6:1192-8. 